\title{
Identification of Para-Bombay blood group in an anemic patient:
}

\section{A case report}

\author{
Manchanayake SMGS, ${ }^{1}$ Subasinghe NDNS, ${ }^{2}$ Samarajeewa SB, ${ }^{3}$ Herath HMAP 4
}

\section{INTRODUCTION}

"Para-Bombay" phenotype is a rare blood group with deficiency of $\mathrm{H}$ antigens on red cell membranes. An anaemic patient investigated at the Immunohaematology Reference Laboratory of National Blood Centre, Sri Lanka was confirmed to have para-Bombay blood type.

\section{CASE REPORT}

A 65 year old male patient was investigated for blood group discrepancy. Historic blood grouping records were not available. He denied previous transfusions.

All tests were carried-out by conventional tube technique using commercially available anti-sera. In $\mathrm{ABO}$ and $\mathrm{Rh}$ $D$ grouping, forward grouping results didn't match with the reverse grouping (Table 01). Screening cells of the antibody screening panel were positive with variable strengths at all three phases (Table 02). All cells in the identification panel gave weak reactions at $37^{\circ} \mathrm{C}$ and $2+$ at Indirect Antiglobulin (IAT) phase. Direct antiglobulin test was negative and cells were negative for $\mathrm{H}$ antigens.

Along with the presence of unexpected reactions with group $O$ cells at the reverse group and antibody panel, rare para-Bombay $O$ group was suspected. The reaction with pooled A1 cells was stronger than other two cells in the reverse group. Due to these differences, genotypic group B was considered as more likely. Adsorption-elusion study confirmed the presence of minute amount of

1.Senior Registrar in Transfusion Medicine, Blood Bank, National Hospital of Sri Lanka, Sri Lanka.

2. Medical Officer, National Blood Centre, Sri Lanka

3. Medical Officer In-charge, Immunohaematology Reference Laboratory, National Blood Centre, Sri Lanka

4. Consultant Transfusion Physician, District General Hospital, Polonnaruwa, Sri Lanka.

Corresponding author: SMGS Manchanayake; email: geethika.manchanayake@yahoo.com

iD https://orcid.org/0000-0002-0247-0714
$B$ antigens on red cells (Table 03). Patient's blood group was taken as para-Bombay Bh (Rh D positive). Patient was negative for both Lewis $a$ and $b$ antigens; thus, we were unable to get a clue regarding the secretor status of the patient. Salivary study was unable to perform due to inadequacy of sample we received. Bombay $O$ red cell unit was compatible with patient's serum and issued for transfusion. His family members were tested and none were having similar blood group phenotype.

\section{Discussion}

Para-Bombay is a very rare type of blood group and only few cases have been reported from India1, Japan2, China3 and Thailand4. To best of our knowledge, this is the first publication from Sri Lanka on this blood group.

Formation of $\mathrm{A}, \mathrm{B}$ and $\mathrm{H}$ red cell antigens occur as the interaction of genes at three separate loci, $A B O$ gene, $\mathrm{Hh}$ and Se genes. These genes code for specific glycosyltransferases that add sugar residue to a basic precursor substance. $\mathrm{H}$ gene (FUT1) is responsible for formation of $H, A$ and $B$ antigens on red cell membranes while Se gene

Table 01: ABO grouping results

\begin{tabular}{|c|c|c|c|c|c|c|}
\hline \multicolumn{4}{|c|}{ Cell grouping } & \multicolumn{3}{c|}{ Serum grouping } \\
\hline Anti-A & Anti -AB & Anti-B & Anti-D & $\mathrm{A}_{1}$ cells & B cells & O cells \\
\hline 0 & 0 & 0 & $4+$ & $4+$ & $1+$ & $1+$ \\
\hline
\end{tabular}

Table 02: Antibody screening result

\begin{tabular}{|l|c|c|c|c|}
\hline $\begin{array}{l}\text { Screening } \\
\text { Cells }\end{array}$ & $\begin{array}{c}\text { Room } \\
\text { Temperature } \\
\left(22-26^{\circ} \mathrm{C}\right)\end{array}$ & $\begin{array}{c}37^{\circ} \mathrm{C} \\
\text { (Direct spin) }\end{array}$ & IAT (Poly/IgG) & $\begin{array}{c}\text { Coomb's } \\
\text { Control } \\
\text { cells }\end{array}$ \\
\hline S1 & $4+$ & $1+$ & $2+$ & \\
\hline S2 & $4+$ & $+/-$ & $1+$ & \\
\hline S3 & $3+$ & $+/-$ & $+/-$ & $1+$ \\
\hline Auto cells & 0 & 0 & 0 & $3+$ \\
\hline \multicolumn{7}{|c|}{ Positive control } & 0 & $1+$ \\
\hline \multicolumn{7}{|c|}{ Negative control } & & \\
\hline
\end{tabular}

Table 03: Absorption elusion study result

\begin{tabular}{|c|c|c|c|c|c|c|c|c|c|}
\hline Reagent Cells & $\begin{array}{c}\text { A } \\
\text { Cells }\end{array}$ & $\begin{array}{c}\text { A } \\
\text { Cells }\end{array}$ & $\begin{array}{c}\text { A } \\
\text { Cells }\end{array}$ & $\begin{array}{c}\text { B } \\
\text { Cells }\end{array}$ & $\begin{array}{c}\text { B } \\
\text { Cells }\end{array}$ & $\begin{array}{c}\text { B } \\
\text { Cells }\end{array}$ & $\begin{array}{c}0 \\
\text { Cells }\end{array}$ & $\begin{array}{c}0 \\
\text { Cells }\end{array}$ & $\begin{array}{c}0 \\
\text { Cells }\end{array}$ \\
\hline $\begin{array}{c}\text { Reaction with } \\
\text { eluate }\end{array}$ & 0 & 0 & 0 & $2+$ & $2+$ & $2+$ & 0 & 0 & 0 \\
\hline
\end{tabular}

The articles in this journal are licensed under a Creative Commons Attribution 4.0 International License. 
(FUT2) is responsible for $A B O$ antigens formation in secretions. Inheritance of hh gene results in rare phenotype named as Bombay 0.5

In para-Bombay phenotypes, red cells are completely devoid of $\mathrm{H}$ antigens or having small amount of $\mathrm{H}$ antigens present due to mutations at genetic level. 2 The responsible genetic alteration is a mutated $\mathrm{H}$ gene with or without active Se gene or a silenced $\mathrm{H}$ gene with active Se gene. The possible genotypes are $\mathrm{Se} / \mathrm{Se}, \mathrm{Se} /$ se or se/se. In situations with mutated $\mathrm{H}$ gene, a small amount of $\mathrm{H}$ antigens are expressed on red cell membrane and all these antigens are converting to A or B antigens (depending on genotype). People with these phenotypes develop Anti- $\mathrm{H}$. In case of silence $\mathrm{H}$ gene with an active secretor gene, $H, A$ and $B$ antigens are present in secretions and they can be absorbed into the red cell membrane.2, 5 The amount of antigens in cell membrane is weak in these situations allowing only detectable by adsorption-elusion studies. 5

Group O red cells which contain the highest amount of $\mathrm{H}$ antigens, give positive reactions with anti- $\mathrm{H}$ leading to unexpected reactions with group $O$ cells at reverse group and antibody panels. Since group B cells also contain considerable amount of $\mathrm{H}$ antigens, an unexpected positive reaction was detected in the reverse group with group B cells as well.

Autologous transfusion and transfusion from family members are some of options for blood transfusion in para-Bombay patients. Selecting blood units from para-Bombay or Bombay blood donor are also possible. Emergency cases should be managed with blood conservative strategies.

\section{CONCLUSION}

Blood group discrepancies should be investigated to identify rare blood groups and to provide most suitable blood for transfusion.

\section{REFERENCES}

1.A.Yashovardhan, I.S.Chaitany Kumar, K.V.Sreedhar Babhu et al. Para-Bombay phenotype: report of a rare blood group. Journal of Clinical and Scientific Research. 2012;3:141-3.

2. Kaneko $M$, Nishihara $S$, Shinya $N$ et al. Wide variety of point mutations in the $\mathrm{H}$ gene of Bombay and para-Bombay individuals that inactivate $\mathrm{H}$ enzyme. Blood. 1997;90:839-49.

3. Lin-Chu M, Broadberry RE. Blood transfusion in the para-Bombay phenotype. British Journal of Haematology. 1990;75(4):568-72.

4. Townamchai, N., Watanaboonyongcharoen, P., Chancharoenthana, W., \& Avihingsanon, Y. (2014).
A case of nearly mistaken $A B$ para-Bombay blood group donor transplanted to a group 'O' recipient. BMJ case reports, 2014,

5.Denise M. Harmening (editor). 2005. Modern blood banking and transfusion practices. 6th ed. Philadelphia: F.A. Davis Company. 